\title{
Tóbiás László: Szakmai életutak az ifjúsági munkában - Bevezetés: ifjúsági munka a rendszerváltás előtt és után
}

Diósi Pál emlékének.

Bányai Emőkének a Párbeszédben megjelent életútinterjú-sorozata abban a tekintetben is inspiráló, hogy elkészítsünk és közzétegyünk egy hasonló sorozatot az ifjúsági munka néhány kiemelkedő hazai szereplőjével. A Párbeszéd interdiszciplináris, befogadó szemlélete mellett a másik oldalról az indokolja sorozatunkat, hogy az ifjúsági munka nem rendelkezik saját fórummal. Az interjúsorozat elé egy bevezető írásra adott felkérést a szerkesztőség: mutassuk be a szociális munka - mint a Párbeszéd elsődleges tárgyköre - és az ifjúsági munka közötti kapcsolatot. Interjúalanyaink közül többen az 1960-as években mint kortársvezetö önkéntesek léptek az ifjúsági munka színpadára, tehát az ő történeteik fél évszázadot ölelnek fel, s a mai ifjúsági munkához is kapcsolódnak. Ez a történeti távlat adja a szakmai értelmét az ilyen sorozatoknak: szakmát gyakorlóknak és szakmát tanulóknak is sokféle stimulust adhatnak a szakmai identitás formálásához.

Írásunk négy részből áll:

1. Bemutatjuk azokat a célokat, amelyeket a szakmai életútinterjúkból álló sorozatunk elé tüztünk

2. Bemutatjuk, mit értünk ifjúsági munkán

3. Bemutatjuk a rendszerváltás előtti évtized ifjúsági munkájának a ma és a szociális munka nézőpontjából fontosnak gondolt jellegzetességét

4. Bemutatjuk a ma ifjúsági munkájának jellegzetességeit a szociális munka felől nézve

1. Sorozatunk elé a következő célokat tüztük ki:

- Az aktív szakmai tevékenységük végéhez közeledő ifjúsági szakemberek személyes élettörténetének gyüjtése. Az interjúalanyok kiválasztása természetesen szubjektív. Írásunk történeti szemléletében alapvető, hogy a rendszerváltás előtti évtizedek ifjúsági tevékenységeit egyértelmüen ifjúsági munkának tekintjük. Nem látjuk és láttatjuk a Magyar Kommunista Ifjúsági Szövetség és a Magyar Úttörök Szövetsége tevékenységét homogénnek, de ifjúsági munkának tartjuk. Akkor is ezt tartanánk a helyes besorolásnak, ha csak politikai szocializációs szerepben látnánk ezeket a szervezeteket, hiszen a politikai szocializáció az ifjúsági munkának alapvető tevékenysége, a polgárnevelés célkitüzése az ifjúsági munka kezdeteinél megjelent minden országban Müller (1992), Temesváry (2018). A kortárs ifjúsági munkának alapvető célkitüzése a participáció, a társadalmi aktivitás, részvétel serkentése Európaszerte, hiszen ez a demokratikus rendszerek müködésének, fenntarthatóságának alapfeltétele. Természetesen külön kérdés, hogy a politikai szocializáció a jelszavak mögött ténylegesen milyen célokat követ, milyen eszközökkel. Egyértelmü, hogy ez a két megnevezett szervezet sem csak politikai szocializációval foglalkozott, nagyon 
sokféle elemből állt tevékenységük. És volt több más szereplő is, amelyeknek tevékenysége egyértelműen ifjúsági munka volt, hogy a sokból csak néhányat említsünk: a művelődési házak, a (nép)müvészeti együttesek, mozgalmak, olvasótáborok, de akár a Magyar Rádió riporterörse.

- Az ifjúsági munka történetéről és állapotáról, annak alakulásáról kiemelkedő ifjúsági szakemberek, alkotók narratíváinak gyüjtése. A magyarországi történelemtanítás és ennek hatására a társadalom történelmi szemlélete túlontúl (szinte kizárólag) hatalmi politikai szemléletü, szakpolitikákról, társadalomtörténetről alig esik szó. Tapasztalható ez a szociális felsőoktatásban is, nappali és levelező tagozatos hallgatókkal dolgozva egyaránt. A szociális professzió sok területén hiányoznak a módszeres kutatások, szociális munkáról, ifjúsági munkáról is, így egyes események, szabályozások és szabályozásváltoztatások, intézmények és rendszerek történetéről is. Vannak hiánypótló vállalkozások, pl. Révész (2007), Nagy Ádám (2016), de ezek nyomán sem alakulnak ki diskurzusok. Kevés az olyan vállalkozás, mint amilyen a társadalmi alapjövedelemről szóló különszáma volt az Esélynek (2010/5), a hozzákapcsolódó konferenciával. Mindennek nyilván sok oka van, egyebek között forrás, idő, megfizetett ráfordított idő (más oldalról nézve: a polgári egzisztencia) hiánya. Mindez felértékeli a szakmai életútinterjúk jelentőségét, egyrészt mint forrásokét, másrészt mint egyfajta feldolgozásokét, értelmezésekét. Nem kritikai kiadásokat készítettünk az interjúkból, nem füztünk jegyzetapparátust, hivatkozásokat a szövegekhez. Önmagukban érvényes interjúkat igyekeztünk készíteni, melyek a müfajból következően történeti forrásként kritikai szemlélettel és más forrásokkal egybevetve használhatóak.

- Az ifjúsági munka és a szociális munka kapcsolatára és annak történetére vonatkozó narratívák gyüjtése. Itt tulajdonképpen egy értelmezési láncról van szó, melynek középső szeme a szociálpedagógia. Az 1980-as évektől a német szakmai nyelvhasználat egy (talán fö)árama túltette magát a szociális munka versus szociálpedagógia vitán, egyaránt fontosnak, egy nagyobb egység részeinek, különböző indíttatású és hagyományú összetevőinek látva ezeket. Temesváry Zsolttól (2018) tudjuk, hogy a német szociális kormányzat is szerepet játszott abban, hogy a vagy helyett az és határozza meg a kapcsolatot, Soziale Arbeit néven, aminek része a Sozialarbeit és a Sozialpädagogik is. Német földön - születésük helyén - az eggyel ezelőtti századelőn felvetett kérdés a szociálpedagógia ifjúsági munkával való viszonya. (Nagy 2017) Mindezeket tehát össze lehet úgy olvasni, hogy az ifjúsági munka, a szociálpedagógia egészeként vagy részeként a szociális munkával együtt alkotja a szociális professziót ${ }^{1}$. Más értelmezések hangsúlyozzák az ifjúsági munka azon sajátosságait, melyeket figyelmen kívül hagyná a szociálpedagógiával való megfeleltetés. Interjúalanyaink is különbözö értelmezésekkel látják ezt a kapcsolatot.

- Annak a kérdésnek a felvetése, hogy a magyarországi ifjúsági munka állapota kíván-e változtatást, és amennyiben igen, milyen tapasztalatok relevánsak az ifjúsági munka történetéből. Jelen írásunknak is alapvető kiindulópontja, hogy a magyar ifjúsági munka sporadikus. Az ifjúsági munka csak töredékét éri el azoknak a fiataloknak, akiket - életkoruk alapján potenciális - célcsoportjának tekint. Kérdés, hogy magának az ifjúsági munkának a fejlesztésére irányul-e szisztematikus tevékenység szakmaként, tudományként, konkrét tevékenységek esetében. Nagyon kevés szervezet végez önállóan, más szervezethez, egyházhoz nem kapcsolódó ifjúsági munkát,

\footnotetext{
${ }^{1}$ Úgy látjuk, hogy a szociális professzió lenne a legalkalmasabb magyarítása, megfeleltetése a Soziale Arbeit kifejezésnek, ezért ezt fogjuk használni és ezt javasoljuk az Olvasónak is.
} 
egyenként pár - nem ritkán egyetlen - szakemberrel, különböző számú önkéntessel. Mindennek alapvető oka a magyar ifjúságpolitika állapota, története, „folyamatos megszakítottsága", ahogy Oross Dániel (2016) nevezi.

A szakmai életútinterjú valójában egy történeti műfaj, melynek sajátossága szerint az interjú készítője igyekszik a lehető legkisebb mértékig feltünni, de a lehető legnagyobb mértékig segíteni, hogy az interjú alanya közlési szándéka a lehető teljességgel megvalósulhasson. Minden interjúalanyunkkal évtizedek óta állunk szakmai kapcsolatban - reméljük, hogy ez inkább erősítette, mint gyengítette a munkát. A sorozat interjúi két ülésben készültek. Első alkalommal narratív életútinterjút vettünk fel, a személyes és a szakmai életút áttekintését is kértük. Második alkalommal strukturált interjúkat készítettünk, alapvetően a szakmai eseményekre, tevékenységekre, tapasztalatokra, véleményekre koncentrálva. A két-két ülés anyagából készítettük el a sorozat írásait. Ennek az írásnak a megalapozásához készítettünk két háttérinterjút, amelyek nem fognak ebben a sorozatban megjelenni. Ennek a két interjúnak az alanyai maguk is alkotó ifjúsági munkások voltak a rendszerváltás előtt, és nyugdíjba vonulásukig a segítő szakmában maradtak, de nem ifjúsági területen, így ennek az írásnak az elkészítéséhez kontrollt, de új információkat is adtak - mindkettőt köszönjük. Segítségünkre voltak Hegyesi Gáborral a Hilscher Egyesület Történeti mühelye kapcsán folytatott beszélgetéseink, inspiráló a Szociális Szakma Digitális Archívuma, amelynek szintén szakmai alkotója Talyigás Katalinnal, a Szociális Innováció Alapítvány színeiben. Köszönet mindezekért!

2. Mit értünk ifjúsági munkán?

Az ifjúsági munka

A magyar ifjúságügy elméletalkotó törekvéseinek Nagy Ádám a legfontosabb alakja, aki vizsgálja a más területekhez való kapcsolódás kérdéseit is. Szerzőtársával foglalkoztak a szociális munkához füződő kapcsolódás kérdéseivel (Nagy-Oross 2016). Legátfogóbb gyüjtőfogalomként beszélnek az ifjúságügyről, amin belül három szintre rendezték a tevékenységeket, azoknak a fiataltól való távolsága alapján.

1. táblázat. Az ifjúságügy rendszere

\begin{tabular}{|c|c|c|}
\hline $\begin{array}{l}\text { Az ifjúsági munka } \\
\text { területei }\end{array}$ & $\begin{array}{l}\text { Az ifjúsági szakma } \\
\text { területei }\end{array}$ & $\begin{array}{l}\text { Horizontális ifjúsági } \\
\text { területek }\end{array}$ \\
\hline $\begin{array}{l}\text { Fejlesztési területek } \\
\text { 1. Egyéni autonómia } \\
\text { fejlesztése } \\
\text { 2. Jövőtervezés } \\
\text { 3. Önkéntességfejlesztés } \\
\text { 4. Részvételérzékenyítés } \\
\text { 5. Személyes ifjúságsegítés } \\
\text { 6. Ifjúsági } \\
\text { közösségfejlesztés } \\
\text { Terepek } \\
\text { 7. Informális csoportok, } \\
\text { mozgalmak } \\
\text { 8. Nonformális és } \\
\text { formális szervezetek } \\
\text { 9. Ifjúsági táborok } \\
\text { 10. Ifjúsági közösségi terek } \\
\text { (pontok és irodák) } \\
\text { 11. Virtuális tér } \\
\text { 12. Ifjúsági projektek }\end{array}$ & $\begin{array}{l}\text { 1. Ifjúság és jog } \\
\text { 2. Ifjúsági kutatások } \\
\text { 3. Ifjúsággal kapcsolatos } \\
\text { tervezés } \\
\text { 4. Feladatrendszerek } \\
\text { 5. Humán rendszerek } \\
\text { 6. Anyagi rendszerek } \\
\text { 7. Nemzetközi ifjúsági } \\
\text { tevékenység } \\
\text { 8. A civil-nonprofit } \\
\text { ifjúsági szegmens }\end{array}$ & $\begin{array}{l}\text { 1. Ifjúság és család } \\
\text { 2. Tanulás és környezete } \\
\text { 3. Fiatalok és a munka } \\
\text { világa } \\
\text { 4. Ifjúság és egészségügy } \\
\text { 5. A fiatal mint fogyasztó } \\
\text { 6. Fiatalok és identitás } \\
\text { 7. Marginalizálódás } \\
\text { 8. Deviancia } \\
\text { 9. Élhető környezet }\end{array}$ \\
\hline
\end{tabular}


Írásunkban elfogadjuk ezt a pragmatista alapvetést: ifjúsági munka a fiatalokkal, illetve közösségeikkel közvetlenül, sajátos terepeken végzett, az életkorhoz kapcsolódó szükségletek kielégítésére hivatott, a szocializációt támogató tevékenységek rendszere. Érdemesnek tartjuk hangsúlyozni, hogy önmagában legitim célnak tekintjük a tevékenység vagy a közösségi lét örömének megélését. Elfogadjuk azt a meghatározást, hogy az ifjúsági munka célcsoportjának a felelős gyerekkor szakaszába lépett, de saját gyerekekért felelősséget még nem viselőket tekintsük, és ne életéveket vegyünk alapul.

Írásunk többször hangoztatott alapvetése lesz, hogy a magyar ifjúsági munka sporadikus és esetleges, nem lehet tudatosan felépített rendszerről beszélni, településtípusonként és térbeli egységenként sem. Ebböl viszont következik, hogy a pragmatikus megközelítés pontosságát óvatosan kell kezelnünk. Ezért választottunk még egy pragmatista, tevékenységjegyzékre épülő meghatározást.

A hatályos német ifjúságjóléti törvény (Sozialgesetzbuch [SGB] - Achtes Buch [VIII] Kinder- und Jugendhilfe, KJHG) 1991. január 1-től hatályos a régi tartományokban, de az egykori Kelet-Németországban hatályba léptették már az egyesülés napján, 1990. október 3án. $^{2}$ A törvény az 1922-ben elfogadott törvénnyel kezdve támaszkodik szabályozási hagyományokra, és a magyar törvénynél több területet szabályoz, így az ifjúsági munkát, az ifjúsági szervezetek támogatását, az ifjúsági szociális munkát, de például a szellemi fogyatékossággal élő fiatalok ellátását is. Ez a törvény így definiál: „11. § ifjúsági munka:

(1) Az ifjúsági munka a fiatalok számára a fejlődésüket támogató lehetőségeket biztosít.

Ezeknek a fiatalok érdekeit kell szolgálnia, és nekik maguknak is el kell fogadniuk őket és részt kell venniük a megalkotásukban, őket az önálló cselekvésre késztetni és közösségi felelősségben való részvételre és szociális elkötelezettségre bátorítani és vezetni.

(2) Ifjúsági munkát végeznek ifjúsági szervezetek, csoportok és kezdeményezések, az ifjúsági munka más nem állami szervezetei és az önkormányzati, állami ifjúságjóléti tevékenységek fenntartói. Felöleli a szervezetek által tagjaik számára, önkormányzati, állami nyílt szolgáltatók által nyújtott és közösségi irányultságú ifjúsági munkát.

(3) Az ifjúsági munka súlypontjai közé tartoznak:

1. az iskolán kívüli ifjúsági képzések az általános, politikai, szociális, egészségre vonatkozó, kulturális, természettudományos és technikai képzésekkel;

2. a sportban, játékban, szocializációban végzett ifjúsági munka;

3. a munka világára irányuló, az iskolai és családi irányultságú ifjúsági munka;

4. a nemzetközi ifjúsági munka;

5. gyerekek és fiatalok rekreációja;

6. ifjúsági tanácsadás."

\footnotetext{
${ }^{2}$ Az írás szerzője a Bundesministerium für Familie, Senioren, Frauen und Jugend és az AGJ programjának ösztöndíjasa volt 2000-ben, amiért ezúton is köszönetet mond. Az írás alapvetően az akkor megismert gyakorlatra és a jogszabály szövegére támaszkodik. Német nyelvü elméleti munkákat a www.agj.de honlapon, illetve onnan elindulva talál az Olvasó - pl. az ifjúságjóléti törvény modernizálását elkészítő vita dokumentumait is.

Fel kell hívjuk a figyelmet arra, hogy lektorált közleményekben is találkozunk következetesen téves fordítással. A törvény nevében szereplö Kinder- und Jugendhilfe fordítása az általunk itt megadott, míg a Hilfe önmagában jelent segélyt is. Természetesen szó sincs róla, hogy a német szabályozás szegény(gyerek)gondozásról szólna csak. Hivatkozásai és szellemisége az emberi jogokra, egyenlőségre, esélyteremtésre építik a szabályozást, így a szöveg tartalma alapján is jólét jelentésével fordítandó a szó.

${ }^{3}$ Saját fordítás.
} 
A törvény megengedi, hogy 27 évnél idősebbek is részesülhessenek az ifjúsági munka szolgáltatásaiból. Kemény életkori plafon arra vezethetne, hogy a fiatalabbak, akik az ifjúsági munka célcsoportjába tartoznak, idősebb társaikkal tartanának, és nem vennék igénybe az ifjúsági munka ajánlatait. A német jóléti szolgáltatásokat nagyvonalúság jellemzi, nem kényszeríti - jelen esetben például életkort - kontrolláló szerepbe a szolgáltatókat.

A törvény 13. §-ában szól az ifjúsági szociális munkáról, mely a támogatott fiatalok számára szociálpedagógiai segítés felajánlását írja elő a iskolai és szakmai képzésük, a munka világába történő, illetve társadalmi integrációjuk támogatására.

Miért fontos a szociális munkások számára az ifjúsági munka?

Úgy gondoljuk, erre a kérdésre már meg is felelt a német törvény, amikor a gyerekek és fiatalok jóléti ellátásának leírását nem akcidentális, hanem életúti krízisek megküzdését támogató szolgáltatásokkal kezdi. Tulajdonképpen a készenlétet, jelenlétet jelenti és nyújtja az ifjúsági munka. Orientációja és eszköztára alapvetően a megküzdési kompetenciák kialakításához nyújt segítséget.

3. A rendszerváltás előtti évtized ifjúsági munkájának a ma és a szociális munka nézőpontjából fontosnak gondolt jellegzetességei

A magyar ifjúsági munka, ifjúságügy egyértelműen létezett a rendszerváltás előtti időkben. A 30 évvel ezelőtti viszonyok nagy hatással vannak a kortárs ifjúsági munkára, bár a rendszerváltás erős határvonal, sok kortárs jelenség a múltból ered, létezett a 80-as években vagy azok elött is. A következőkben felvázoljuk azokat a körülményeket, amelyeket a leginkább meghatározónak tekintünk a mai ifjúsági munkára, és annak a szociális munkához kötődő kapcsolata szempontjából. Bár talán határozottabban írunk, az Olvasót kérjük, leginkább hipotézisekként olvassa szövegünket. Egy narratívának - részben - narratív interjúk felvezetéseként. A 80-as évek ifjúsági munkáját még csak szélességében sem próbáljuk megragadni, különösen nem átmetsző mélységben és teljes szélességben. Szeretnénk bátorítani és támogatni, hogy Olvasónk történeti perspektívából is tekintsen a - korunkat is meghatározó jelenségekre. Persze az idő - és a történések - még a 80-as éveknél is régebben kezdődött, de nem nyúlhatunk itt a végtelenségig, csak ott tekintünk korábbra, ahol ezt elengedhetetlennek látjuk.

1957 után az Úttörőszövetségnek szinte minden általános iskolás a tagja volt, pedagógusaiktól elvárt volt, hogy tanítványaik gyerekszervezeti vezetői is legyenek. A Magyar Kommunista Ifjúsági Szövetségnek nagyon nagy arányban tagjai voltak a középiskolások, alacsonyabb, de magas arányban az egyetemisták és a már dolgozó fiatalok. A politikai rendszer egészének elerőtlenedése erodálta a szervezettséget, amin szervezeti és tevékenységi változtatásokkal próbáltak változtatni. A 80 -as évek ifjúsági munkája egyáltalán nem látható egységesnek. Fontos háttérinformáció, hogy első gyermekük megszületésekor a nők átlagosan 23 évesek voltak 1990-ben, 2013-ban pedig 28,2 évesek, ugyanezen idő alatt az apává válás életkora 5 évvel tolódott ki, 34 éves korára a férfiaknak (Kapitány, Spéder 2018), tehát akkortól vállaltak felelősséget másokért, zárult le fiatal koruk, léptek ki az ifjúsági munka kompetenciaköréből, a már ismertetett mai, nem életkoralapú ifjúságdefiníció szerint.

Valószínűleg a közösségi szabadidős lehetőségek biztosítása volt a mindenütt megjelenő tevékenységi elem, önépítő szervezői közösségekre támaszkodva. Egy kettős közösségiség élt: az alkalmak, események megvalósításában a résztvevők nagy része aktív volt, nem (csak) 
szolgáltatást vett igénybe, vállalt kisebb-nagyobb feladatot, ami arcot adott a közösségben, lehetőséget az egyéniségként való jelenlétre. A szervezés, az előkészítés és a vezetés feladataira szerveződő munkacsoportok egy része a szó szűk értelmében is közösségként müködött, továbbá ilyen közösségek között hálózatok alakultak ki. Ezt stimulálták különböző képzések, a helyi közösségeket közös tevékenységekre mozgósító akciók, járási, megyei, országos és nemzetközi rendezvények. Vitathatatlan ezek politikai demonstrációs célja, ugyanakkor ezen tevékenységek kompetenciafejlesztő hatása és az is, hogy sok ilyen közösség nemcsak az életút előrehaladásával járó nehézségeket élte túl, de a szervezetek eltünését is. Mindmáig léteznek olyan informális közösségek, kapcsolathálózatok, melyeket a 60-as, 70-es, 80-as években gyermek-, ifjúsági szervezeti keretben születtek. Az ilyen közösségek és a bennük épült kapcsolatok és kompetenciák meghatározóak lehettek abban, hogy az egyesülés szabaddá válása, az 1989. évi II. törvény életbelépése után megindult szervezetalapítási hullámban az ifjúsági célú szervezetek is nagy részt képviseltek ${ }^{4}$. A korábbi szervezetekben született közösségek, hálózatok egy része közvetlenül vagy informális létezésben töltött időszak után újabb formális keretbe szerveződtek. Ebben annak jelét látjuk, hogy ezek a közösségek tényleges szükségletek kielégítői voltak, bár (kvázi) kötelező tagságon alapuló szervezetekben születtek.

Hangsúlyozottan hipotézisként vetjük fel, de vizsgálatra nagyon is érdemes hipotézisként, hogy a rendezvények és közösségek fontos funkciója volt a párválasztás lehetöségének biztosítása. A falvak, városok, városrészek, társadalmi csoportok fiataljai számára találkozási lehetőséget biztosító bálok, a vállalati szabadtéri mulatságok, a munkásmozgalom, majd a nagyüzemek által kötelezően fenntartandó munkásjóléti intézmények, müvelődési házak, müvészeti és sportkörök mind töltöttek be ilyen funkciót a II. világháború elött. A társadalmi változások miatt másként teljesült ez a funkció az 50-es években, és minden bizonnyal megvoltak a sajátosságai a 80 -as években. A mind szabadabbá váló gazdaság szabadidős kínálata inkább egyéni igényekre kínált kielégítést, új trendeket, fogyasztói szokásokat is teremtve. Az ifjúsági munka kiszorult a közösségi szórakozás, szabadidőtöltés teréből, nem utolsósorban azért, mert a csőd szélére érő állam már nem finanszírozta ezt a tevékenységet. A fiatalok pedig már inkább akartak a piac logói között együtt lenni, mint a KISZ és az Úttöröszövetség zászlai alatt.

Jelentősnek kell feltételeznünk a képzés súlyát a tevékenységek között. Ennek politikai szocializációs szerepe nem vitatható. Hangsúlyos volt a közösségszervezés-és vezetés tanítása, illetve a nem formális pedagógiai eszközök alkalmazása, ezzel együtt átadása. Ilyen szerepe volt a közösségi művelődéshez kapcsolódó képzéseknek: klubvezetők, színjátszó és egyéb művészeti csoportokat vezetők képzésének, a megyei vagy országos művelődési központok szervezésében. ${ }^{5}$ A mozgalmak képzései egyaránt szóltak olyan szerepet betöltőknek, akiket mai fogalmainkkal kortárs vezetőknek, illetve ifjúsági munkásoknak neveznénk. A közösségi müvelödési képzések alapvetően (legalább fél-) professzionális szerepre készítettek fel, amit szintén ifjúságimunkás-szerepnek neveznénk ma. ${ }^{6}$

\footnotetext{
${ }^{4}$ Ezt a feltételezést nem tudjuk alaposabban vizsgálni, mert a civil szektor 1993 óta létező statisztikai adatgyüjtése a gyermek- és ifjúsági érdekvédelem kategóriát használja, amin belül nem különíthetőek el a ténylegesen a fiatalok részvételével működő szervezetek.

${ }^{5}$ Egyszerre szakmai és szépirodalmi igénnyel írt erről Diósi Pál (2016).

${ }^{6}$ Egyszerre szakmai és szépirodalmi igénnyel írt erröl Diósi Pál (2016), akinek kutatásai negyven éven át újra és újra visszatértek ehhez a témához is.
} 
Az érdekképviselet, érdekérvényesítés funkciójáról aligha lehet általános képet alkotni. Egyik háttérinterjúnk alanya két olyan szempontot is kapcsolt ehhez a témakörhöz, amelyek talán kevésbé ismertek. Elmondása szerint a 70-es években a középiskolai KISZ az ideológiai szocializációtól némileg a diákönkormányzatiság felé fordult. A települési KISZ-bizottságok külső támogatást igyekeztek adni a diákok kezdeményezéseinek, igyekezvén bontogatni az iskolák zárt és rigid világát. Ettől a kortól eredeztette a diákparlamentek intézményét. A másik meglátás azokra a választott KISZ-vezetőkre vonatkozik, akik rész- vagy teljes állásban alkalmazottai is voltak a szervezetnek. A választás titkos volt, ́́gy ezeknek az embereknek az egzisztenciája függött attól, hogy miként ítélik meg választóik a munkájukat, benne az érdekképviseleti szerepvállalásukat és eredményességüket. Így a rendszer, a szervezet és a vezető legitimitását egyszerre érintették a munkahelyen belüli érdekérvényesítés eredményei, alapvetően jóléti szolgáltatásokban, vállalati üdülésben, (KISZ) lakásépítésben.

Egyéni segítségnyújtás nem nagyon volt jellemző. A formális társsegítő tevékenység a KISZen kívül jelent meg, a 80-as évek közepén. A SOTE mentorprogramja, illetve a pécsi egyetemisták kortárssegítő-képzése az elsők között volt. 1972-ben indult jelent meg az erősen szociokulturális indíttatású olvasótábori mozgalom (Kamarás, 2004). A költségvetési pénzből a Hazafias Népfront által pályázati rendben adott támogatásból progresszív kulturális közösségi projektek is születtek. A projektgazdák egy része különleges szükségletü csoportokkal dolgozott, cigány fiatalokkal, olyan diákokkal, akiknek a családjából már a szakmunkásképző is nagy ugrás volt (Forray R., Hegedüs T. 1991). 1984. szeptember 29-én megnyílt az budai Flórián téri aluljáróban az ország első ifjúsági információs és tanácsadó irodája (-kara- 1984). Ez a szolgáltatás kifejezetten egyéni szükségletek kielégítése szándékával, helyi kezdeményezésre született, az ötletgazda nevét is megőrizte az emlékezet: Péteri János szociológus, a kerületi pártbizottság munkatársa volt (szp. 1987). A piciny iroda a Várkonyi György Úttöröház telephelyeként kezdte meg munkáját. 1987 áprilisában, majd 1988 augusztusában az Állami Ifjúsági és Sporthivatal a KISZ Központi Bizottságával írt ki pályázatot ilyen intézmények létrehozatalára (Szabó 2006). Tehát az ifjúsági munka egyéni szükségletek kielégítését célzó intézménye helyi kezdeményezésként fél évvel korábban született meg, mint a Társadalmi Beilleszkedési Zavarok kutatási fő irány javaslata alapján, politikai döntéssel az első családsegítő szolgálatok. Utóbbiakat kísérletképpen javasolták beindítani, akár egy-két évtizedet is adva országos körü kiépítésükre.

Segélyezési funkciót nem töltött be az ifjúsági munka, munkahelyeken legfeljebb a szakszervezeti segélyekhez való hozzáférésben, (információ)közvetítésben volt szerepe. Adományozási funkció megjelent: (nem csak saját rendeltetésű) terek, klubok, ifjúsági házak, táborhelyek építése mellett munkajövedelmet is gyüjtöttek lokális, hazai és nemzetközi szolidaritási célokra. Nem Zánka építése volt az egyetlen cél, aminek mind helyszíni munkavégzéssel, mind pénzadományokkal való támogatására mozgósított nemcsak a KISZ, de még az Úttöröszövetség is, utóbbi például hulladékgyüjtési akciókkal. Ezeknek a tevékenységeknek mindenképpen volt szolidaritási és érzékenyítő szocializációs hatása.

Az ifjúságpolitika jelentős teljesítménye volt az 1971. évi IV. törvény az ifjúságról, amely egészen a rendszerváltásig hatályban volt.

A társadalompolitika az 1970-es évek végére kénytelen volt szembenézni a társadalom anómiás jelenségeivel, a lakosság általános állapotával, a devianciákkal, különösen az 
öngyilkosság és alkoholbetegség magas arányával. A jelenségek okainak és összefüggéseinek megértésére indították a társadalmi beilleszkedési zavarok kutatási föirányt (Társadalmi beilleszkedési zavarok Magyarországon [1986]). Ez a magyar társadalomtudomány és holisztikus szemléletben kapcsolódó társtudományok példátlanul finanszírozott, termékeny és színvonalas időszakát hozta el, aminek sok kutatása értelemszerüen a fiatalokra (is) irányult. ${ }^{7}$ Továbbá a KISZ országos vezetése is rendelt meg, finanszírozott (állami támogatásából) kutatásokat, tehát az ifjúságpolitikusok és a kutatók együttműködésében választották ki a kutatási témákat. A KISZ Központi Bizottsága periodikája volt az Ifjúsági Szemle, amely 1981-89 között kéthavonta jelent meg. A 2003 végén indult - és 2011-ben megszünt - Új Ifjúsági Szemle ifjúságelméleti folyóirat nemcsak nevével tisztelgett a 80-as évek lapja előtt, de első számában annak repertóriumát is közzétette. Ez az önmagában is érdekes olvasmány, kutatási adatbázis 17 témakörbe rendezte az írásokat, melyek nagyobb része átfogó társadalmi kérdésekkel foglalkozott. Leginkább a következő címek alá gyüjtött írásokról gondoljuk azt, hogy az ifjúságüggyel és az ifjúsági munkával, ezek témáival, tevékenységeivel, az általuk felvállalt problémákkal közvetlenül kapcsolatban álltak: Ifjúság és munka, Ifjúság helyzete, Ifjúság életmódja, Ifjúság és kultúra; müvelődés; szabadidő, Szexualitás, család, nemek, Kisebbségek Magyarországon - magyarok kisebbségben. A folyóiratot értelmiségiek írták értelmiségieknek.

Léteztek kimondottan a fiataloknak szánt egyedi és rendszeresen megjelenő sajtótömegtermékek, leginkább az Ifjúsági Lapkiadó Vállalat kiadásában. Eléggé egyértelmüen a negyedszázados Kádár-rendszer propagátorai voltak az egyedi kötetek mellett az általános iskolásoknak szánt lapok is, 1947-50 között kéthetente, majd 1987-ig hetente jelent meg a Pajtás, az 1957-89 között hetente a Magyar Ifjúság és 1965-89 között havilapként az Ifjúsági Magazin is. De a propaganda mellett megjelentek a fiatalok nagy témái, közöttük a párkapcsolati, szexuális tanácsadás is. Utóbbiak a tanácsadás-tanácskérés személyes kapcsolati hálón kívüli lehetőségeit felmutatva és kínálva, minden bizonnyal minden segítő szakma dolgát könnyítették. A Magyar Rádió és Televízió ifjúsági műsorai szélességét néhány müsorral és témával illusztráljuk: Kék fény, Mit üzen a rádió? (Általános tanácsadó és kijáró müsor volt: a riporter helyre tette a kizökkent dolgokat, megsegítve a kisembert, akár fiatalt.) Volt évekig tartó müsorsorozat az újonnan épült budapesti Havanna utcai paneltelep lakóinak közösséggé szerveződési kísérletéről. A telepen lakó fiatal müsorgazda a (mikrofont fegyverként is használó) részt vevő megfigyelő valószínűleg elsőként állította a legszélesebb közönség elé a közösségszerve(ző)dés kérdéseit.

A TBZ-kutatás eredményeként megfogalmazott javaslatok között szerepelt a létező szolgáltatások jó tapasztalatai alapján a lelkisegély-telefonok elterjesztése, fejlesztése (Társadalmi beilleszkedési zavarok Magyarországon, 1986: 121-122). Érdekes az az óvatosság, ahogy felveti a szöveg önkéntesek foglalkoztatásának lehetőségét - szakemberek mellé: „egyes nézetek szerint...” Más, a mából nézve kényesebbnek tünő témákat határozottabban vetett fel: „támogatni kell - anyagilag is - a különféle önkéntes - egyházi és más szervezésű - telefonszolgáltatások létrehozását; ki kell dolgozni ezek szakmai irányításának, felügyeletének formáit."

\footnotetext{
${ }^{7}$ A kutatási összefoglalók, javaslatok szemlélete és nyelve ma is előremutató, a „kor színvonalán álló”. Ez egyrészt a szerzők kvalitásaiból és teljesítményeiből is következik, de abból is, hogy sok probléma ma is velünk él, illetve a kezelésükre irányuló szak- és közpolitikák nem nőttek fel a kutatások színvonalára. Kérdés, hogy nem utolsósorban a politikák színvonala miatt - a kezelésre irányuló szakmák, közöttük a szociális munka és az ifjúsági munka felnőttek-e a TBZ elemzési színvonalára.
} 
A TBZ-javaslatok között másutt is megjelennek az egyházak, közösségeik. Tomka Ferenc katolikus papként a szocializmus éveiben is végzett ifjúsági munkát, teológiai professzorként és szociológiadoktorként is értelmezve. Írásai segítenek a történeti látáshoz (Tomka 2005).

Úgy gondoljuk, hogy a rendszerváltás előtti ifjúsági munka nagyon kiterjedt volt. A 80-as évek elején alapvetően tagsági viszony volt az alapja az ifjúsági munkának, kényszerített tagság. A tömegszervezetek közösségei egymástól minden tekintetben nagyon különbözőek voltak. Általánosnak tünnek a közösségi kompetenciákat fejlesztő késztetések. A rendszerváltáshoz érve a kényszer elfogyott, és a finanszírozás is. Az ifjúságügy egésze légüres térbe került, az ifjúságkutatás is, miközben a fiatalok alapvetően új helyzetbe kerültek. A fiatalok egyéni szükségleteire válaszolva az ifjúsági munka legjobb teljesítményei is helyiek, egyediek voltak - az egyéni ifjúságsegítésre életre hívott ifjúsági információs és tanácsadó irodából is mindösszesen 19 létesült az országban, több igen rövid idő után átalakult, bezárt. Az egyházi ifjúsági munka motívumai változatlanok maradtak, de a hatalmitársadalmi változások, még a presszió megszünte is új kihívásokat adtak.

\section{A mai ifjúsági munka - a szociális munka felé nyúló szálakkal}

A következőkben a mai ifjúsági munka néhány jellegzetességére fogunk rátekinteni, azokra, melyek a szociális munkával való kapcsolat szempontjából relevánsak. A hivatkozott olvasmányok kapcsán sokat fogunk találkozni Nagy Ádám nevével, aki az ifjúságügy elméletalkotásának, kutatásának és publikációinak kiemelkedő szervezője, szerzője. Az Új Ifjúsági Szemle, a Civil Szemle elindítása, az ifjúságsegítő szakképzéshez tankönyvnek szánt munkák szervezése és szerkesztése és írása után újabban az MTA Szociálpedagógia Albizottság szervezése, alelnöki feladatai kötődnek a nevéhez. Ez a dominancia az elkötelezettségen túl abból is következik, hogy az ifjúságügy egyetlen szakirány erejéig van jelen a felsőoktatásban ${ }^{8}$ : 2018 nyarán a kormány kifuttatta a felsőoktatási szakképzést is, annak előtte sem kellett sokféle tankönyvet írni, szakhoz kapcsolódó területen kutatni. Így a hivatkozott szerzők önkéntes munkában építik az ifjúságügy tudásbázisát - legújabban már gerillaként is (Nagy 2018).

Az ifjúságügy a rendszerváltás óta sem tudott a magyar közbeszédnek még a perifériájára sem kerülni, nemhogy a középpontjába. Az ifjúságot érintő egyes kérdések ideig-óráig reflektorfénybe állították a közoktatás, a felsőoktatás, a foglalkoztatás, a lakáshoz jutás, az elvándorlás, a sorkatonaság és annak megszüntetése stb. ügyeit, a drogproblémát, viselkedési zavarokat... De éppen a szakterületeket átmetsző szemlélet nem látszik érvényesülni, ami az ifjúságügy definíciója mögött áll.

Alapvető állításunk, hogy a rendszerváltás óta a magyar ifjúságügy alakulása még inkább esetleges és sporadikus.

Az országos, kormányzati ifjúságpolitikai szint kérdéseivel itt hely hiányában sem foglalkozunk, továbbá azért, mert erről korszakot átfogó elemzések állnak rendelkezésre (Nagy, Bán, Folmeg, Schmidt 2017; Nagy 2016), de leginkább azért, mert nem látjuk ennek a

\footnotetext{
${ }^{8}$ A közösségszervezés alapszakon, melynek képzési és kimeneti követelményei a 18/2016. (VIII. 5.) EMMI rendelet 1. mellékletében jelentek meg.
} 
szintnek az építő hatását jelen írásunk témájára, az ifjúsági munkára és annak kapcsolatára a szociális munkával.

A rendszerváltás óta eltelt időszak érdekegyeztetése általában és az ifjúsági, illetve a szociális munkához kapcsolható ügyekben sem hozott sokat. Elérhetőek szakértők elemzései (Nagy 2016).

A szakmai képzés kérdéséröl is csak röviden szólunk, rövidesen erröl is áll rendelkezésre egy tanulmánykötet, az ifjúságsegítő felsőoktatási szakképzési szak megszüntetése utáni számvetés (Nagy 2019), illetve rendelkezésre áll Monostori Ádám, Monostori Éva, Nyári Kitti (2015) és Schmidt Richárd, Bán Dóra, Márton Balázs (2017a) írása. Itt a szakmagyakorlás és -képzés tyúk-tojás problémájáról akarunk szót ejteni, egy személyes élmény alapján is kiegészítve ezeket az írásokat. Egy szakértői megbeszélést hívott össze a minisztérium főosztályvezetője, ami a konkrét téma megvitatása után a szakmafejlesztés aktuális országos teendőiről szóló beszélgetéssé alakult. Nagyon heves vita alakult ki a pécsi egyetemnek adott megbízásról és anyagi támogatásról, aminek eredményeként „képzés egyedül a Pécsi Tudományegyetemen folyt 2006-2008 között, ahol összesen egy csoport végzett" (Schmidt, Bán, Márton 2017a). Magunk az ifjúsági munka értékvilágával összeegyeztethetetlennek ítéltük, hogy egy egyetem nyilvános verseny nélkül kapott megbízást, de alapvetően azt vitattuk, hogy a képzés megelőzi az ifjúsági munkások foglalkoztatásának, az ifjúsági munkát végző intézmények létrehozásának, finanszírozásának. Ha sporadikusan is, de létezett ifjúsági munka. Egy szociális munkásokat képző tanszékről nézve - mely az Iskolaszövetségben a szociális képzésekről folyó szakmai diskurzusoknak is aktív résztvevője volt -, egyértelmü volt, hogy az ifjúsági munka szakmai tudásbázisa, miként a szociálismunka-tudomány praxisalapú és interprofesszionális. Tehát a gyakorlat felől kell felépíteni a teljes ifjúságügyet, nem a képzés felől. Álláspontunkat sajnálatunkra igazolták a beindult ifjúságsegítő képzések tapasztalatai. Nem egy olyan képzés volt, amelynek egyetlen oktatójának sem volt semmilyen tapasztalata sem arról, mit is csinál az ifjúsági munka. Volt amelyiknek a közelében nem volt olyan intézmény, ahol ifjúsági munkát végeztek, ahová legalább terepgyakorlatra lehetett volna küldeni a hallgatókat. Intézmények hiányában persze az ifjúságszakma területén elhelyezkedni sem tudhattak a végzettek. Az egykori vita persze a kritika megfogalmazásán túl nem juthatott, hiszen a döntés már megszületett. Fontos érv volt, hogy a posztgraduális képzéshez szükséges csekély forrást a főosztályvezető tudta biztosítani, az intézményrendszer formálásához még modellprogramok pályázati finanszírozására sem lehetett forrást mozgósítani, nemhogy kötelező feladat előírására. Ifjúságpolitika nélkül nem épülhet fel az ifjúságügy. Köztisztviselői pozícióból nem lehet politikát csinálni.

1995 és 2013 között létezett a Mobilitás, mint az ifjúságszakma állami intézménye, módszertani tevékenységgel és országos irodahálózattal. A név további elemei és az intézmény elhelyezése a kormányzati háttérintézmények között rengeteget változott. Nem járnánk messze az igazságtól, ha azt állítanánk, hogy többet volt érdemi működésre képtelen a szervezet az átszervezések miatt, mint amennyit produktívan müködött. Maradandó eredmény módszertani kiadványok és elektronikus kiadványgyüjtemény létrehozása. ${ }^{9}$ Ez a munka alapvetően a jó gyakorlatok felől építkezett. Az ott található anyagok időt állóak, fiatalokkal dolgozó szociális munkások által is jól használhatóak, például a Kapcsoskönyv (Földi, Nagy, Járosi 2010). 2011-12-ben a szociális ágazat országos módszertani feladatait is ellátó Nemzeti

\footnotetext{
${ }^{9}$ Nemzeti Ifjúsági Információs és Dokumentációs Adattár, http://www.mobilitas.hu/niida/index.html.
} 
Család- és Szociálpolitikai Intézet részeként müködött a Mobilitás, de akkor sem közelítették egymáshoz érdemben a szociális és ifjúsági területet. A Mobilitás megszünéséről és helyébe az Új Nemzedék történetéről több összefüggésben szól több írás (Nagy-Szeifer, 2016; Schmidt - Bán - Márton 2017)

„Az európai fősodor az ifjúsági munkát az ún. ifjúságügy mágikus háromszögében értelmezi (Williamson 2002; 2007; Milmeister, Williamson2006; Chisholm et al. 2011), ahol az ifjúságkutatás (mint elmélet), az ifjúságpolitika (mint közpolitika) és a szociálpedagógiai irányultságú ifjúsági munka (mint gyakorlat) hat egymásra (1. ábra). Az ifjúsági munka ilyen értelemben az ifjúságügy gyakorlati részeként értelmezett, ahol az ifjúságkutatás hozza felszínre, jelzi a fiatalokkal kapcsolatos jelenségvilágot, problémákat, az ifjúsági (köz)politika transzformálja feladatokká és az ifjúsági munka építi be ezen feladatokat, megoldásokat, módszereket a mindennapi ifjúsági tevékenységbe (1. ábra):

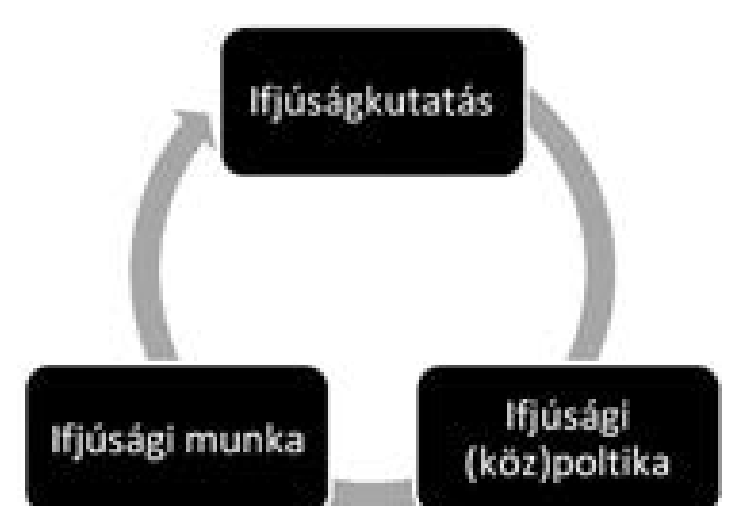

1. ábra. Az európai ifjúságügy-értelmezés

Forrás: saját szerkesztés

„Mindez nemcsak önmagában tudományos tényként fontos, hanem a szolgáltató rendszerek tervezése, a szükségletekhez való igazítása, fejlesztése, kiegészítése, paraméterezése kapcsán is lényeges." (Nagy 2017)

Azért idéztünk ilyen hosszasan, mert úgy látjuk, itt a szerző álláspontja legalábbis nem egyértelmü, a vita kedvéért úgy is fogalmazhatunk, hogy önellentmondásban látjuk. Az első mondat és az ábra, illetve a második mondat és a lábjegyzet mást mond. Az első mondat egymásra hatásról szól, irányultság jelölése nélkül. Az ábra egyetlen nyílheggyel konvencionális módon kapcsolatot jelöl: a nyíl az ifjúsági munkáról mutat a kutatásra, ezt mi úgy értjük, a gyakorlatról az elméletre. A második mondat értelmezése a kutatást teszi kiindulóponttá, a lábjegyzet pedig tudományos ténynek nevezi, ami önmagán túli gyakorlati zsinórmérték. Úgy látjuk, a második mondat és a lábjegyzet nem a valóság leképezése. A mi álláspontunk szerint az európai ifjúsági munka és vele a szociálpedagógia 1876 nyarán kezdődött el, amikor Walter Bion tiszteletes zürichi szegény gyerekeket küldött vidékre, jó levegőre, jó kosztra. A sok alkotása alapján ma is a svájci szociális gondoskodás nagy alakjaként tisztelt bölcs és alázatos Bion felismerte, hogy olyan feladattal bízza meg a kísérő pedagógusokat, amilyet elöttük még senki nem végzett, felhívta a figyelmüket, hogy ennek tudatában igyekezzenek aktívak lenni. Továbbá azt kérte, hogy minden gyerekről, illetve minden tevékenységről vezessenek naplót. Ezen feljegyzések és a pedagógusok le nem írt tapasztalatai alapján 1877-ben már felkészítették a feladatra a pedagógusokat. (Rauch, (1992). 
És hasonlóan dolgozott a kortárs ifjúsági munka (szociálpedagógia), amikor sorsukra várva tömegével rekedtek meg Szicíliában és Lampedusán a Földközi tengerből összegyüjtött fiatal menekülők, és ifjúsági munkások elkezdtek velük foglalkozni: tevékenységeket szerveztek, csoportokat, traumafeldolgozással igyekeztek segíteni... Tehát egyértelmüen az az álláspontunk, hogy az ifjúsági munka találkozik elöször a fiatalok - új - szükségleteivel és reagál is rájuk. A mindennapi munkában nincs is idő elemzések eredményére várni, ha megszakad az interakció, elvész a kapcsolat is, ami a segítő szakmák alapvető bázisa. Tehát az ifjúsági munka a szociálpedagógia tudományát éppen úgy praxistudománynak látjuk, mint a szociális munka tudományát.

Megint visszatérünk ahhoz az alapvető állításunkhoz, miszerint a magyarországi ifjúságügy sporadikus, így az ifjúsági munka és az ifjúságkutatás is. Az általános kutatási gyakorlatban is hiányzik a stratégiai építkezés, a szociológiában, a pedagógiai, a szociális munka, az ifjúsági kutatásban is. ${ }^{10}$ Így a gyakorlat még az elméletileg tényleg lehetségesnél is kevésbé tud támaszkodni a kutatásra. A rendszerváltást követő években talán három helyen alakult ki hosszabb időre erős kapcsolat ifjúsági munkát végzők és helyi kutatási bázis, illetve felsőoktatás között - aminek feltétele, hogy mindkét oldal erös legyen: Pécsen a Tetthely és az egyetem együttmüködésében, Székesfehérváron az Echo működésében a kutatóintézeti és ifjúsági szolgáltatói párhuzamos munkájában, a Kodolányi Főiskolával együttmüködve, és Kecskeméten. A magyar települések közül talán utóbbi rendelkezik évtizedek óta a legkiépültebb ifjúsági intézményrendszerrel - jelenleg a Hírös Agórába szervezve -, benne szakmai fejlesztőközösséggel. A tanítóképző ifjúságsegítő-képzést indított, és müködtette a Iuvenis Ifjúságszakmai Műhelyt. Minden bizonnyal fontos hatása van minderre az Európa Jövője Egyesületnek, amely 30 éve nemcsak egy kétévente megrendezett gyermekvilágtalálkozó gazdája (43 országból voltak már résztvevők!), de egy meghatározó lobbiszervezet is a gyerekek és fiatalok ügyeinek fókuszban tartására. Gyakorlati szakma és tudományos bázis kapcsolata és a lobbiszervezetek kérdése is releváns a szociális munka számára.

Az 1990-ben létrehozott HAYICO Magyarországi Ifjúsági Információs és Tanácsadó Irodák Szövetsége bázisán 2011-ben született meg az Ifjúsági Szolgáltatók Országos Szövetsége, az ifjúsági szakma általános szervezeteként. A honlapon három tucat szakértő nevét találjuk - a tagoké ennél kevesebb. Ha azt gondolnánk - reménykedve, de alaptalanul -, hogy a nyílt ifjúsági munkában ennél egy nagyságrenddel többen dolgoznak, akkor sem beszélnénk ezernél több hivatásos ifjúsági munkásról az egész országban.

A települési ifjúsági referensek (akik gyakran drog- és/vagy civil szervezeti ügyekkel is foglalkoznak), jellemzően polgármesteri vagy alpolgármesteri kabinetek szakértői, akik nem gyakorolnak intézményirányítási feladatokat, többnyire még a munkájukat segítő munkatársuk sincs. Ezek tanácsadói munkakörök, a mandátumuk a vezető támogatása, s csak ennek keretei között maguknak a fiataloknak, illetve az ifjúsági szakma szempontjainak a megjelenítése. Települési szinten is csak nagyon ritkán látunk töretlen, legalább alapjaiban állandó ifjúságpolitikát. Nemcsak a helyi hatalmi váltások veszélyeztették a folytonosságot, de több helyen megtörtént, hogy az évtizedes távlatban is jó ifjúsági munkát irányító szakember és az önkormányzat, gyakran személyében a polgármester között tört meg a kapcsolat, ami intézmények ellehetetlenüléséhez, megszüntetéséhez is vezetett. Semmiképpen

10 Erre a tapasztalatra ad egyfajta választ Budai István-Huszti Éva-Hüse Lajos (2018) és Budai IstvánSzöllősi Gábor (2018) az MTA Szociológiai Tudományos Bizottság Szociális Munka Albizottság ajánlásait megfogalmazva kutatási témakörökre. 
nem lehet az ifjúságügy sajátos magyar gyakorlatáról beszélni, hacsak nem a hiányt tekintjük sajátosságnak, ami országos és települési szinten is jellemző. Ha kiépült lenne az intézményés szolgáltatási rendszer - mind ifjúsági, mind szociális munkában -, kézenfekvő lenne az együttmüködés, adott körülmények között a kommunikációs csatornák fenntartása önmagában felemészti az erőket.

A referensek alapvető feladata a településen ifjúsági munkát (is) végző szervezetekkel való kapcsolattartás, a szervezetek bekötése a település ifjúságot érintő fejlesztéseibe, pályázataiba. A nyitott ifjúsági munkának alig vannak intézményei - a szociális munka felől nézve a müvelődési intézményeket előadás- és tanfolyamkínálatukkal nem tekintjük annak -, így a települések nagy részén csak civil szervezetek képviselik az ifjúsági munkát. Már ahol vannak. A kistelepülések külön kategóriát képeznek, de közel sem egységeset, még azok sem, ahol van integrált közösségi szolgáltató tér. A kistelepülési egyházi ifjúsági munka lehetőségeit is behatárolja, hogy a középiskolások más városokba járnak, illetve nagyon kevésféle szakmát lehet helyben gyakorolni, így vagy az ingázást kell vállalni, vagy elvándorolnak a fiatalok. Utóbbit ösztönzi a szolgáltatások szegényessége is.

1992-ben létrejött a Települési Gyermekönkormányzatokat Segítők Egyesülete, Beke Pál 2001-es kötetében „vagy negyven” települési gyermekönkormányzatot említ (Beke 2001: 109). Jöttek létre középiskolások alkotta ifjúsági önkormányzatok is. 2000-töl a 12 ezer lakosú Büki Hegyhát 10-18 évesei választották a Kamaszparlamentet, mely 2004-től a kistérség fejlesztési programjában is szerepet kapott, lévén kiemelt célként tűzték ki a fiatalok helyben tartását. Az Örhegy Egyesület eredetileg 1996-ban Ózd és Kazincbarcika környékén indította ezt a települési határokon túlnyúló gyerek- és ifjúsági önkormányzati kezdeményezést (Farkas 2007). Nagyon változatos, hogy mikor, hol, milyen módon müködhettek gyerek- és ifjúsági önkormányzatok. Zugló egy időben helyi rendeletben osztotta meg saját jogkörét az ifjúsági önkormányzattal, egyes ifjúságérdekü témakörökben egyetértési jogot adva a kezdeményezési jog mellé. ${ }^{11}$ Ma nem találjuk nyomát ebben a kerületben diákönkormányzatnak, másutt pedig éppen most prosperál. Teljesen esetlegesnek, leginkább a polgármester szándékától függőnek látjuk az ilyen intézmények születését és eltünését. A Kamaszparlament körül alakítottak gyerekönkormányzatban tapasztalatot szerzett fiatalok egyesületet olyan térségfejlesztő munkára, amely a fiatalokat helyben maradásra késztetné. Ezeknek a tehetséges és képzett fiataloknak másutt jóval kedvezőbb lehetőségeket kínált a piac. Az ugyanilyen célra alakult Zalai Hazatérők Egyesületét talán több szerencse kíséri, eleve kedvezőbb a megye fekvése is. Úgy látjuk, a települési közösségi munka is a szociális munka és az ifjúsági munka találkozási pontja - lehetne.

A gyermek- és ifjúsági szervezetekről, a civil szektor ezek által alkotott szegmenséről nagyon nehéz számokat mondani, itt nem is fogunk ennek a módszertani kihívásnak a kezeléséhez. Két feltétel biztosan hiányzik az európai országok számunkra irányt adó gyakorlatához, pl. a hivatkozott Németországéhoz képest. Ezekről a táboroztatás kapcsán legalább negyedszázada van szó Magyarországon is. Az állami kontroll, garanciavállalás és finanszírozás, legalábbis a támogatás kérdéseiről, melyek egymáshoz is kapcsolódnak. A már hivatkozott német törvény szerint az ifjúsági hivatal megvizsgálja az ifúságjóléti tevékenység fenntartójaként regisztrálást kérő szervezetet. A befogadott szervezet költségvetési támogatásra is jogosulttá

11 Diósi Pál a Zuglói Önkormányzat megbízásából készített elemzésit 2003-tól publikálta, ezek konkrét cselekvési javaslatokkal is éltek. (Diósi, 2007) 
válik. Van egy intézmény, amelyet szintén érdemes lenne átvenni a széles európai gyakorlatból, ez pedig a közremüködők személyes licence, ami képzésre alapuló vizsga letételét igazolja a gyerekekkel végzett munka alapvető kérdéseiben. Ez mindenekelőtt egy biztonsági garanciális eszköz, ha nem is lehet elégséges önmagában. A 120 órás képzést és az ahhoz kapcsolódó vizsgát az önkénteseknek kell teljesíteniük, a munkavállalásnak szigorúbb képesítési feltételei vannak. Ha az ifjúsági munkában képzett önkéntesek dolgoznának - és föleg sokkal több gyerek, fiatal venne részt ifjúsági munka által kínált tevékenységekben -, az ifjúsági munka érdemi partnerré tudna válni a gyermekjóléti jelzőrendszerben. Ez komoly találkozási felülete lenne az ifjúsági és szociális munkának. Gyarapodó azoknak a szakmai szervezeteknek a száma, melyek magasan képzett, elsősorban fiatal embereket készítenek fel önkéntes feladatokra, majd foglalkoztatnak. A Bátor Tábor sok tekintetben példaadó ezen a téren. A gyermekjóléti területen hasonló az Ágota Alapítvány, mely nem csak magasan képzett és fiatal önkéntesekkel dolgozik.

Az egyházi ifjúsági munkáról sem tudunk sokat országos összesítésben, de azt feltételezzük, hogy már hosszú ideje ez a legszervezettebb, legkiterjedtebb, és sok képzett embert foglalkoztat. Gyülekezeti közösségi munkájukban sokan hasznosítják foglalkozásuk szerinti világi képzettségüket. A nagy egyházak képzik az ifjúsági munkát vállaló tagjaikat, csoportvezetőiket. A hitoktatók, felekezeti közösségszervezők és a lelkészek képzési programjaiban is vannak módszertani elemek a gyerek- és ifjúsági közösségi munkára. Rendszeres csoportok, akciók, napközis és bentlakásos táborok is formái az egyházi ifjúsági munkának. A gyülekezeten kívüli és kimondottan hátrányos helyzetü gyerekekre is koncentráló ifjúsági tevékenysége például a református egyháznak a Bárka Tábor, mely a saját intézmények ellátottjain túl más fenntartók intézményeiből is fogad gyerekeket. Itt is találkozik a szociális és ifjúsági munka és az egyházi munka.

Nemzetközi ifjúsági munka alapvetően az EU programjaiban valósul meg, melyek nem nemzeti, hanem központosított, nemzeti ügynökségek a lebonyolításban müködnek közre. A programok tartalmaznak kifejezetten hátránykiegyenlítő eszközöket. A nyelvtudás hiányának kiegyenlítése a legnehezebb, ami Magyarországon is nagy akadálya olyan fiatalok bevonásának, akikkel szociális munkások dolgoznak. Viszont az ő intézményeik fogadhatnak külföldi önkénteseket. Az EU mellett például nemzetközi egyházi szervezetek is finanszíroznak nemzetközi önkéntesprogramokat. Német fiatalok a Máltai Szeretetszolgálat Egyesület intézményeiben is teljesítik polgári szolgálatukat. A nemzetközi ifjúsági munkában leginkább civil szervezetek aktívak, melyek jó része nyitott közös projektek megvalósítására, itt is együttműködhetnek szociális és ifjúsági munkások.

\section{És végül}

Ezen az íráson dolgozva az a benyomásunk alakult ki, mintha a magyar írások egy részében az ifjúsági munkának csak jövőbe mutató dimenziója lenne, például a kompetenciák fejlesztése, az informális tanulás. Úgy gondoljuk, hogy az ifjúsági munkának és a szociális munkának is kell a jelenre irányulnia örömteli tevékenységekkel, magával a tevékenység önmagáért való örömével is erőhöz segítenie. Vagy csak jól megélni az időt.

A folyóirat következő számaiban megjelenő interjúk elé:

A sorozatban megjelenő interjúk alanyai, a hosszú pályákból is csak egy-egy momentumot kiragadva a bemutatáshoz: 
Woostch Péter, az Ifjúsági és Sportminisztérium közigazgatási államtitkára

Szabó András, Kapocs Ifjúsági Önsegítő Szolgálat Alapítvány vezetője

Rapi István, Ferencváros ifjúsági és drogprevenciós referense

Szabó Enikő, a Gyulai Ifjúsági Központ szakmai vezetője

\section{Irodalomjegyzék}

A szociális munka globális definíciója (2014): Párbeszéd - szociálismunka-folyóirat, 1-2.

BEKE M., DITZENDY K. A. (szerk.) (2008): Integrált közösségi és szolgáltató terek. Módszertani kézikönyv. HROD Közösségi Társadalomfejlesztési Központ, Budapest.

BEKE P. (2001): Méltóságkereső. Shark Print Kiadó, Kaposvár.

FARKAS É. (2007): Kamaszparlament, avagy a demokrácia iskolája. Parola, 4. 28.

FORRAY R. K., HEGEDÜS T. A. (1991): Cigánygyermekek háromhetes tábora 1990-ben: Egy multikulturális kutatás kísérleti kontrollja. Új Pedagógiai Szemle, 41(12). 72-81.

FÖLDI L., NAGY Á., JÁROSI É. (2010): Kapcsos könyv. Mobilitás Országos Ifjúsági Szolgálat, http://www.mobilitas.hu/kapcsos/.

KAPITÁNY B., SPÉDER ZS. (2018): Gyermekvállalás. In MONOSTORI J., ÖRI P., SPÉDER ZS. (szerk.) (2018): Demográfiai portré, 2018. KSH Népességtudományi Kutatóintézet, Budapest.

-kara- (1984): Ott, ahol a hatos megáll... Magyar Ifjúság, 1984/38 p. 6.

MONOSTORI Á., MONOSTORI É., NYÁRI K. (2015): Szakmai képzés - elhelyezkedés. In NAGY Á. (szerk.) (2015): Miből lehetne a cserebogár? - Jelentés az ifjúságügyröl. Magyarország: ISZT Alapítvány, Budapest.

Müller, C. Wolfgang (1992): Hogyan vált a segítés hivatássá? A szociális munka módszertanának története 1883-1945. Budapest: ELTE Szociológiai Intézet Szociálpolitikai Tanszék, Hilscher Rezső Szociálpolitikai Egyesület és a T-Twins Kiadó könyvsorozata.

NAGY Á. (2019): Az ifjúságsegítő képzés elméleti legitimitása. Nagy Ádám (szerk. 2019): Hol volt, hol nem volt... Az ifjúságsegítő képzés Magyarországon, Neumann János Egyetem Iuvenis Ifjúságszakmai Máhely, Ifjúságszakmai Társaság Alapítvány, Kecskemét-Budapest

NAGY Á. (2018): Előszó - Az írástudó felelőssége. In: Nagy, Ádám (szerk.) Margón kívül: magyar ifjúságkutatás 2016 . Budapest, Excenter Kutatóközpont, (2018) pp. 5-6.

NAGY Á., BÁN D., FOLMEG B., SCHMIDT R. (2017): Ifjúsági esélyek, ifjúságpolitika In: Ferge, Zsuzsa - Magyar társadalom- és szociálpolitika (1990-2015), Budapest, Osiris Kiadó 
NAGY Á. (2017): Ifjúsági munka: a XXI. század szociálpedagógiája? In: Nagy Ádám (szerk.) (2017): Tizenkilencre lapot? Szociálpedagógia a XXI. században. Pallasz Athéné Egyetem - Iuvenis Ifjúságszakmai Mühely, ISZT ALapítvány

NAGY Á. (szerk.) (2016) 25 év - Jelentés az ifjúságügyről. Budapest, Magyarország: ISZT ALapítvány, Iuvenis - Ifjúságszakmai Mühely

NAGY Á. (szerk.) (2015): Miből lehetne a cserebogár? - Jelentés az ifjúságügyről. Magyarország: ISZT Alapítvány, Budapest.

NAGY Á. (szerk.) (2016): 25 év - Jelentés az ifjúságügyről. Magyarország: ISZT Alapítvány - Iuvenis Ifjúságszakmai Mühely, Budapest.

NAGY Á. (2017b): Ifjúsági munka: a XXI. század szociálpedagógiája? In NAGY Á. (szerk.) (2017): Tizenkilencre lapot? Szociálpedagógia a XXI. században. Pallasz Athéné Egyetem - Iuvenis Ifjúságszakmai Mühely, ISZT Alapítvány.

NAGY Á. (2018): Előszó - Az írástudó felelőssége. In NAGY Á. (szerk.): Margón kívül: magyar ifjúságkutatás 2016. Excenter Kutatóközpont, Budapest. 5-6.

NAGY Á., BÁN D., FOLMEG B., SCHMIDT R. (2017a): Ifjúsági esélyek, ifjúságpolitika In -FERGE ZS.: Magyar társadalom- és szociálpolitika (1990-2015). Osiris Kiadó, Budapest.

NAGY Á., OROSS D. (2016): Az ifjúságügy értelmezése. Esély, 6. 98-120.

OROSS D. (2016): A magyar ifjúságpolitika „folyamatos megszakítottságának” története. In NAGY Á., OROSS D. (szerk.): Ifjúságügy-szöveggyüjtemény. UISZ Alapítvány, Budapest. 257-278.

SCHMIDT R., BÁN D., MÁRTON B. (2016): Negyedszázad ifjúságügyének szakmai háttere és kutatási alapjai. In NAGY Á. (szerk.) (2016): 25 év - Jelentés az ifjúságügyröl. Magyarország: ISZT Alapítvány - Iuvenis Ifjúságszakmai Mühely, Budapest.

Sozialgesetzbuch (SGB) - Achtes Buch (VIII) - Kinder- und Jugendhilfe (KJHG), https://www.gesetze-im-

internet.de/sgb_8/BJNR111630990.html\#BJNR111630990BJNG000205140.

SZABÓ CS. (szerk.) (2006): Kézikönyv ifjúsági információs és tanácsadó szolgáltatások szervezéséhez. Helpi Ifjúsági Információs és Tanácsadó Iroda, Kecskemét.

szp. (1987): Gazdaszemle. Magyar Ifjúság, 1987 25. pp. 8.

Társadalmi beilleszkedési zavarok Magyarországon (1986). Kossuth Könyvkiadó, Budapest. TÓBIÁS L. (2003): Az ifjúsági munka szakma- és szektorközi együttmüködés. In TÓBIÁS L. (szerk.): MindenGyerek - Konferenciakötet. Magyarország: Gyerekparadicsom Alapítvány, Budapest. 1-7.

TÓBIÁS L. (2009): Ifjúsági munka és szociális munka. Család, Gyermek, Ifjúság, 18 : 3 . 4345. 
TÓBIÁS L. (2014): A segítés, mint a társadalmon végzett munka és az ifjúságügy. In ELEK T. (szerk.): Összebeszélünk - $\quad$ 1. Ifjúságügyi Kongresszus. Magyarország: ISZT Alapítvány, Budapest. 26-30.

TÓBIÁS L. (2015): Intézmények és folyamatok a magyar ifjúságügyben. In NAGY Á. (szerk.): Miből lehetne a cserebogár? - Jelentés az ifjúságügyről. ISZT Alapítvány, Budapest. $38-47$.

TOMKA F. (2005): Halálra szántak, mégis élünk! - egyházüldözés 1945-1990 és az ügynökkérdés. Szent István Társulat, Budapest. 